\title{
Species Richness of Butterflies (Papilionoidea) at Natura Park, Xalapa, Veracruz, Mexico
}

Fernando Hernández-Baz ${ }^{1 *}$, Dalia J. Luna Perez ${ }^{1}$, Gerardo Castro Bobadilla ${ }^{1}$, S. Bradleigh Vinson ${ }^{2}$, and Jorge M. González ${ }^{3,4}$

\begin{abstract}
The butterflies at Natura Park in Veracruz, Mexico, were studied during their annual peak in abundance. Butterflies were collected from 21 March through 21 June during spring 2014, for a total of 14 days of collection which were equivalent to 126 hours of fieldwork. Recorded were 775 specimens of 120 species in 81 genera, 15 subfamilies, and five families (573 specimens of 68 species of Nymphalidae, 135/25 of Pieridae, 31/11 of Lycaenidae, 27/nine of Papilionidae, and nine/seven of Riodinidae). The species richness indicated that March was the month with the largest number of species (71), with Nymphalidae the dominant family. In a curve of accumulation of species, the asymptote did not become stable, while Chao 2 estimated the presence of 173 species versus the 120 found, indicating an absence of 50 species still to be reported. Results of the study were compared with the fauna at Xalapa, Veracruz. It was observed that 64 species were exclusive to Natura Park and 56 species were found at both study areas. The Jaccard Index showed $70 \%$ similarity in species between both study areas. The species Danaus plexippus plexippus L. and Eumaeus childrenae (G. Gray) seem to be threatened.
\end{abstract}

Resumen. Se estudiaron las mariposas durante el máximo pico de presencia en el Parque Natura en Xalapa, Veracruz, México. Los muestreos se realizaron durante la época de primavera entre el 21 de marzo al 21 de junio del 2014, para un total de 14 días de recolecta, equivalente a 126 horas de trabajo de campo. Se registraron 775 individuos, pertenecientes a 120 especies en 81 géneros, 15 subfamilias y 5 familias (Papilionidae: 9 especies con 27 ejemplares; Pieridae: 25/135; Lycaenidae: 11/31; Riodinidae: 7/9, y Nymphalidae: 68/573). La riqueza indica que marzo fue el mes con mayor cantidad de especies $(n=71)$ y la familia dominante fue Nymphalidae. En la curva de acumulación de especies no se estabiliza la asíntota y Chao 2 estima la presencia de 173 especies contra las 120 encontradas, lo que indica que falta 50 especies por registrar. Se hizo una comparación entre el presente estudio y la fauna de Xalapa, Veracruz. Se observó que 64 especies son exclusivas para el parque Natura y 56 especies en común entre ambas zonas de

\footnotetext{
${ }^{1}$ Facultad de Biología-Xalapa, Universidad Veracruzana, Zona Universitaria, Circuito Gonzalo Aguirre Beltrán, s/n, C.P. 91000, Xalapa, Veracruz, México.

${ }^{2}$ Department of Entomology, Texas A\&M University, College Station, TX 77843-2475; bvinson@tamu.edu

${ }^{4}$ Department of Plant Sciences, California State University, Fresno, CA 93740-8033; gonzalez.jorge.m@gmail.com

${ }^{5}$ Research Associate, McGuire Center for Lepidoptera \& Biodiversity, Gainesville, FL.

*Corresponding author e-mail: fhernandez@uv.mx; ferhbmx@yahoo.com.mx
} 
estudio. El índice de Jaccard nos muestra una similitud del 70\%. Las especies Danaus plexippus plexippus L., y Eumaeus childrenae (G. Gray) son reportadas como amenazadas.

\section{Introduction}

One of the natural phenomena most studied by ecologists is gradual increase in numbers of animal and plant species along gradients (Currie 1991). In this context, the cloud forests of Mexico need to be preserved and protected, mainly because of their biological wealth (Wilson 1988). These forests are important because of their extraordinary biodiversity (CONABIO 2010). Thus, they are hotspots for priority conservation (Myers et al. 2000). However, mountainous cloud forests are also some of the ecosystems that are most threatened at the national level.

This work is the first in a series on Lepidoptera in the "Ecological Park Natura". This is one of 101 natural areas protected by the government in Veracruz, Mexico (Rodríguez et al. 2011). Recent studies of the butterflies of the State of Veracruz indicated 735 species of Papilionoidea (Lycaenidae, Nymphalidae, Papilionidae, Pieridae, and Riodinidae) (Hernández-Baz et al. 2010, Luis-Martinez et al. 2011). Although the studies provided relevant information on butterflies of Veracruz State, more details on species richness and seasonality are needed.

The "tropical montane cloud forests" or "cloud forests" of Mexico are between 600 and 3,100 $\mathrm{m}$ in zones with heavy precipitation. These forests are along the Eastern Sierra Madre (Veracruz, San Luis Potosi, and Tamaulipas), Northern Sierra (Chiapas), Mother Sierra of the South (Guerrero and Oaxaca), and areas of Jalisco (Rzedowski 1978).

Although native Papilionoidea of the central region of Veracruz have been studied (Godman and Salvin 1878-1901; Hoffmann 1940; Llorente 1984; Llorente et al. 1986; Rodríguez 1986; Hernández-Baz 1989, 1991, 1993, 1994; Luis et al. 1995, 2003; Hernández-Baz and Iglesias 2001; Hernández-Baz et al. 2010; Luis-Martinez et al. 2011), little is understood of the faunal composition of most protected areas of the state, mainly because they are not only reservoirs of native, but also of exotic fauna. Study of Lepidoptera, among other insects, can provide relevant clues about the fauna of an area. In relation to the richness of Lepidoptera in the Central region of Veracruz, Hernández-Baz $(1989,1993)$ and Llorente et al. (1986) confirmed two population peaks per year. The first peak occurs during May-June, while the second occurs in September-October representing the highest richness and abundance of species. We sampled emergence of Lepidoptera during the spring (May-June period). The aim of this work was to determine the richness of Papilionoidea in the Ecological Park Natura during the spring season.

\section{Materials and Methods}

Study Area. The Ecological Park Natura (N 9653'39.82; W 19³0'42.26) has 84 ha and is located east of the city of Xalapa in Veracruz. The northern boundary of the park limits with the Mexico-Veracruz federal highway, to the south is the road axis Arco Sur, to the east is Anahuac University and the Pastoresa Division, and to the west is the Xalapa 2000 habitable unit (GEV 2001) (Fig. 1ab). The habitats of the park are between 1,289 and 1,331 m above sea level (Rossignol 1987). According to the Koeppen classification modified by García (1988), the 


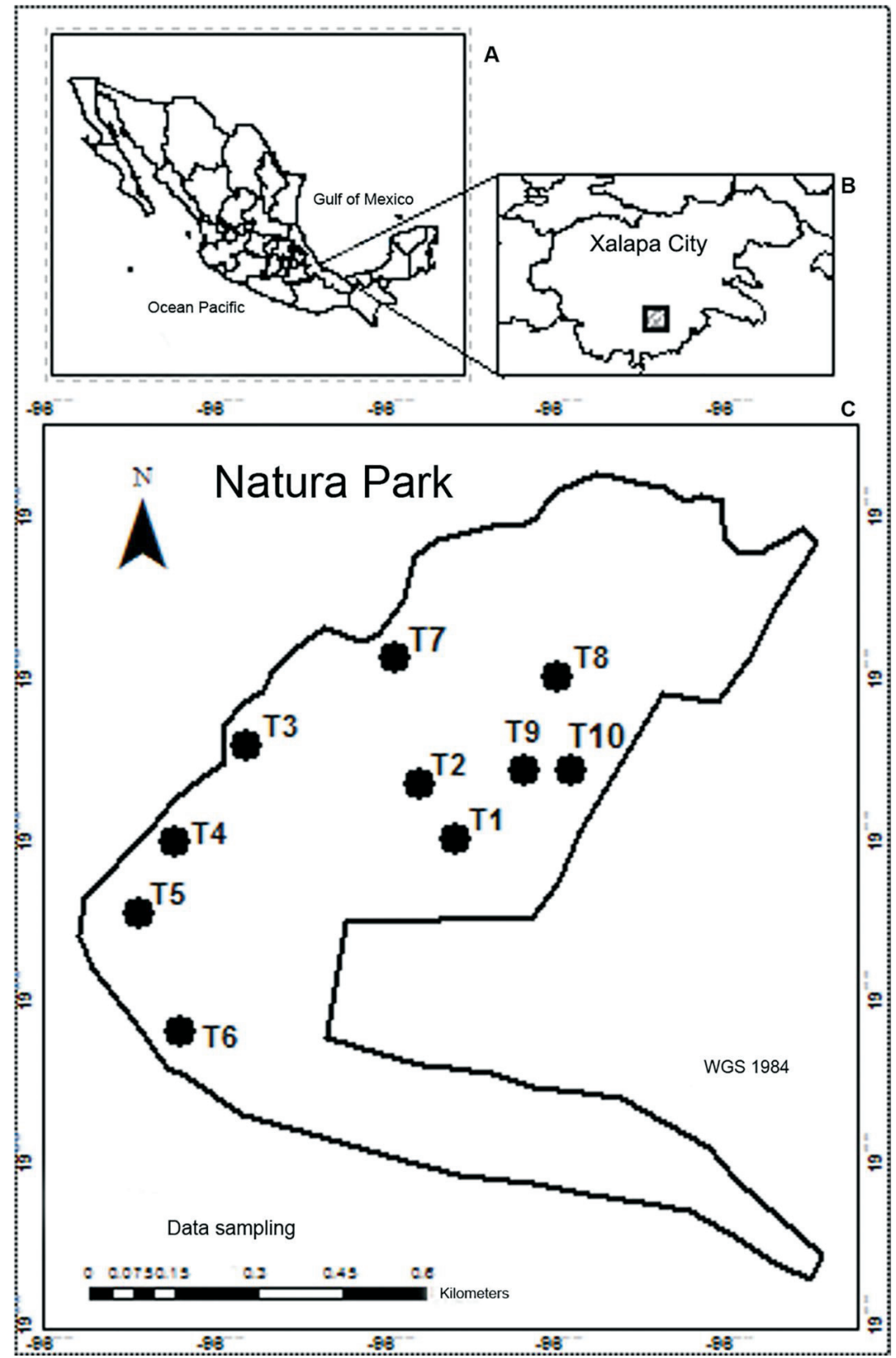

Fig. 1. A. Location of the study site in México. B. Location of the study site (small square) within the Xalapa Municipality, Veracruz, México. C. Map showing the location of Van Someren-Rydon baited traps (T1 to T10) along a 10-km transect at Natura Park, Xalapa, Veracruz, México. 
climate is $(A) C(m) a\left(i^{\prime}\right) g$ semi-warm and humid. The annual mean temperature oscillates between 18 and $22^{\circ} \mathrm{C}$. Annual total precipitation is between 1,500 and $2,000 \mathrm{~mm}$ (Soto and Gómez 1990). There are large areas of cloud forest, but in general the vegetation is mature "acahual" (abandoned areas of secondary vegetation in different successional development stages) (Castillo 1991).

Field Sampling. Specimens were collected between 0800 and 1700 hours 1 day per week from 21 March until 21 June during spring 2014, for a total of 15 samples. Two people used the method of Directed Search (Búsqueda Dirigida-BD) (Pozo et al. 2005). A trail of $10.5 \mathrm{~km}$ around the perimeter of Ecological Park Natura was walked every collection day. The trail crossed three types of vegetation: secondary vegetation with coffee, Coffea arabica L. (Rubiaceae), shaded by trees, Meadows-Huizachal (geological formation dating to the Triassic Period), and plain meadow. Two techniques were used to collect/record specimens: a) visual record-butterfly netting and b) capturing moths by using Van Someren-Rydon traps (Rydon 1964) at sites previously selected along the trail and in areas with the basic vegetation types of the park (Fig. 1c). Ten baited traps were used every collecting day. The bait was a mixture of water, cane sugar, ripe plantain, and beer. Each trap was $10 \mathrm{~m}$ above the ground. All specimens collected were killed by ethyl acetate and placed with appropriate field data into glassine triangles. Specimens were collected under scientific license FAUT-0194 (SEMARNAT) of the first author. All material was processed using techniques developed by Steyskal et al. (1986).

Taxonomic Determination. All collected and prepared specimens were separated to the morph-species level to be grouped into the different Papilionoidea families (Lycaenidae, Nymphalidae, Papilionidae, Pieridae, and Riodinidae) by using simple comparison techniques, Triplehorn and Johnson (2005) keys and data previously gathered by Hernández-Baz et al. (2010). Identification of the specimens was corroborated by comparison with material deposited at the National Collection of Insects of the Institute of Biology of Universidad Nacional Autónoma of México in Mexico City. For certain taxa within complex groups difficult to identify (such as some Nymphalidae in the genera Adelpha, Anaea, Anthanassa, and Hamadryas), we relied on the work of Luis-Martínez et al. $(2003,2010)$ and Vargas-Fernández et al. (2008). Once identified, all specimens were recorded as DF-CC-276-13 of SEMARNAT and placed into the Lepidoptera collection of the Biology School of Universidad Veracruzana, Xalapa, and their curatorial data were put into the Data Base "Polilla" (Hernández-Baz 2012).

Analysis. Species accumulation curves were created with the use of STIMATES software (Colwell 1997) to calculate Chao 2 and Independent Cost Estimates that use presence-absence data for any given sample with few samples. The estimates give relevance to species richness when the number of samples is small and provide an estimate of the number of species in the studied locality and the sample unit used (Jiménez and Hortal 2003). The information was compared with faunal studies by Hernández-Baz (1993) allowing comparison of similarity between species of two sampled zones (Xalapa and Natura Park) by using the "Jaccard index" that provides the degree to which two samples are similar in the species at two sites (Villarreal et al. 2004). A taxonomic list of all Papilionoidea at Natura Park was provided. 


\section{Results and Discussion}

Species Richness. After 14 days of fieldwork, equivalent to 126 collection hours, we obtained 775 specimens of 120 species of Papilionoidea in a total of 81 genera and 15 subfamilies in the families: Nymphalidae (573 specimens in 68 species), Pieridae (135 specimens in 25 species), Lycaenidae (31 specimens in 11 species), Papilionidae (27 specimens in nine species), and Riodinidae (nine specimens in seven species) (Table 1). Sampling showed that 57 species of which 39 were Nymphalidae, 13 Pieridae, three Riodinidae, and two Papilionidae were collected in March (Fig. 2). The smaller total number of specimens was collected in April, with 32 Nymphalidae, nine Pieridae, two Lycaenidae (a family not found in March), two Riodinidae, and one Papilionidae. These low numbers in April were possibly due to warmer temperatures associated with low relative humidity that tended to dehydrate pupae, limiting eclosion of imagoes (Hernández-Baz 1993, Moyers and Cano 2009). With rains beginning in May, richness increased (66 species). With more humidity, more Lepidoptera imagoes were seen flying and visiting flowers because many plant species were blooming (Hernández-Baz 1993). Most species (71) were collected in June. Nymphalidae was the family with the most species during the spring. The specific richness by month was: 57 in March, 46 in April, 66 in May, and 71 in June.

The accumulation of species curve estimated with Chao 2 (Fig. 3) indicated that the asymptotes did not stabilize and simple effort was insufficient. It estimated 173 species instead of the 120 actually recorded, for a difference of 53 taxa. This meant that the collecting effort determined only $69.4 \%$ of the species richness during the spring. Six extra samples should have been collected to accurately complete the spring list.

The Independent Cost Estimates can be stabilized only with a large number of samples, indicating it is an index affected by the number of samples collected. The Independent Cost Estimates index estimated that the number of species in the studied area should have been 182 (Fig. 4) which also meant a longer collecting period was needed to reach stability. It confirmed a similar percentage as estimated with Chao 2 -- 65\% for species at Natura Park. Species richness increased during the spring, as previously determined by Hernández-Baz (1993).

With the techniques used, 775 specimens (= 120 species) were collected. The baited traps captured 298 specimens (38.5\%) in 37 species $(30 \%)$, of which 20 were collected exclusively by this technique [i.e., Smyrna blomfildia datis (Fruhstorfer) that uses mid and high strata and Consul fabius cecrops (Doubleday) that also is found in the canopy and has a fast and vigorous flight pattern].

Table 1. List of Papilionoidea of the Natura Park, Xalapa, Veracruz, Mexico. $X=$ indicates that the species was collected during that month.

\begin{tabular}{|c|c|c|c|}
\hline \multirow[b]{2}{*}{ Taxa } & \multicolumn{3}{|c|}{ Spring 2014} \\
\hline & March April & May & June \\
\hline \multicolumn{4}{|l|}{ Papilionidae: Papilioninae } \\
\hline 1 Parides photinus (Doubleday, 1844) & & $\mathrm{X}$ & $X$ \\
\hline 2 Mimoides thymbraeus thymbraeus (Boisduval, 1836) & & $\mathrm{X}$ & $\mathrm{X}$ \\
\hline 3 Heraclides astyalus pallas (Gray, [1853]) & & $\mathrm{X}$ & $X$ \\
\hline $\begin{array}{l}4 \text { Heraclides thoas autocles (Rothschild y Jordan, } \\
1906 \text { ) }\end{array}$ & $\mathrm{X}$ & $\mathrm{X}$ & \\
\hline
\end{tabular}


5 Heraclides cresphontes (Cramer, 1777)

6 Heraclides anchisiades idaeus (Fabricius, 1793)

7 Papilio polixenes asterius Stoll, 1782

8 Pterourus menatius victorinus (Doubleday, 1844)

9 Protographium epidaus epidaus (Doubleday, 1846)

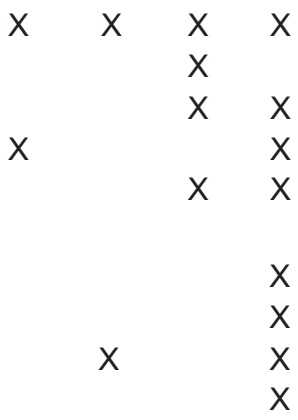

Pieridae: Dismorphiinae

10 Enantia albania albania (H.W. Bates, 1864)

11 Enantia mazai mazai Llorente,1984

12 Enantia jethys (Boisduval,1836)

13 Dismorphia amphione praxinoe (Doubleday,1844)

Pieridae: Coliadinae

14 Pyrisitia nise nelphe (R.Felder,1869)

15 Pyrisitia proterpia (Fabricius, 1775)

16 Pyrisitia dina wetswoodi (Boisduval,1836)

17 Eurema daira eugenia (Wallengren, 1980)

18 Eurema Salome jamapa (Reakirt,1866)

19 Eurema mexicana mexicana (Boisduval, 1836)

20 Eurema daira sindonia (R. Felder, 1869)

$\begin{array}{lll}X & X & x \\ x & x & X \\ & x & X\end{array}$

21 Eurema arbela boisduvaliana (Felder \& Felder, 1865)

22 Anteos maerula (Fabricius, 1775)

23 Anteos clorinde (Godart,[1824])

24 Nathalis iole (Boisduval,1836)

25 Phoebis argante ssp. $\mathrm{n}$.

26 Phoebis sennae marcellina (Cramer,1777)

27 Phoebis philea philea (Linnaeus, 1763)

28 Phoebis neocypris virgo (Butler,1870)

Pieridae: Pierinae

29 Leptophobia aripa elodia (Boisduval,1863)

30 Catasticta flisa flisa (Herrich-Schäffer,[1858])

31 Catasticta nimbice nimbice (Boisduval,1836)

32 Ascia monuste monuste (Linnaeus, 1764)

33 Hesperocharis costaricensis passion (Reakirt,1867)

34 Pontia protodice (Boisduval y Leconte, [1830])

$x$

$x \quad x$
$x$

$x \quad x \quad x$

$x$

$X \quad X$

$x$

$X \quad X \quad X \quad X$

$X$

$X$

$x$

$\mathrm{X} \quad \mathrm{x}$

Lycaenidae: Theclinae

35 Strymon serapio (Godman \& Salvin, 1887)

36 Strymon albata (C. Felder \& R. Felder, 1865)

37 Arawacus sito (Boisduval,1836)

38 Ostrinotes halciones (Butler \& H. Druce,1872)

39 Eumaeus childrenae (Gray, 1832)

40 Rekoa marius (Lucas, 1857)

$\begin{array}{llll}X & X & X & X \\ X & X & X & X\end{array}$

$x$

$x$

$X \quad X$

$X$

$X$

$x$

$X \quad X$

$x$

$x$

$\mathrm{X}$

Lycaenidae: Polyommatinae

41 Zyzula Cyna (W. H. Edwards,1881)

42 Echinargus isola (Reakirt, [1867])

43 Leptotes cassius cassidula (Boisduval, 1870)

$x$
$x \quad x$
$X \quad X$ 
44 Hemiargus sp. 1

45 Cupido sp. 1

$x$

$X$

Riodinidae: Riodininae

46 Calephelis sp. 1

47 Calephelis sp. 2

48 Calephelis sp. 3

49 Calephelis sp. 4

50 Calephelis sp. 5

51 Thisbe lycorias (Hewitson, [1853])

52 Emesis tenedia (C. Felder \& R. Felder, 1861)

Nymphalidae: Danainae

53 Lycorea ilione albescens (Distant,1876)

54 Danaus gilippus thersippus (H.W. Bates, 1863)

55 Danaus plexippus plexippus (Linnaeus, 1758)

Nymphalidae: Ithomiinae

56 Mechanitis polymnia lycidice (H. W. Bates, 1864)

57 Mechanitis menapis doryssus $(\mathrm{H}$. W. Bates, 1864)

58 Dircenna klugii klugii (Geyer, 1837)

59 Pteronymia artena artena (Hewitson, [1855])

60 Greta morgane oto (Hewitson, [1855])

Nymphalidae: Morphinae

61 Opsiphanes cassina fabricii (Boisduval, 1870)

Nymphalidae: Satyrinae

62 Manataria hercyna maculata (Hopffer, 1874)

63 Pareuptychia ocirrhoes ssp.n

64 Oxeoschistus tauropolis tauropolis (Westwood, 1850)

65 Hermeuptychia hermes (Fabricius, 1775)

66 Yphthimoides renata (Stoll, 1780)

67 Euptychia westwoodi (Butler, 1867)

68 Cyllopsis hilaria (Godman 1901)

69 Cyllopsis hedemanni hedemanni (R. Felder, 1869)

70 Cissia pompilia (C.Felder \& R. Felder, 1867)

71 Taygetis sp.

Nymphalidae: Charaxinae

72 Fountainea eurypyle confusa (A. Hall, 1929)

73 Fountainea glycerium glycerium (Doubleday,[1849])

74 Fountainea halice martinezi (J. Maza y Díaz, 1978)

75 Consul electra electra (Westwood, 1850)

76 Consul fabius cecrops (Doubleday, 1849)

77 Anaea trglodyta aidea (Guérin-Méneville, [1844])

78 Memphis philumena xenica (H. W. Bates, 1864)

79 Memphis moruus boisduvali (W. P. Comstock, 1961)

80 Memphis pithyusa pithyusa (R. Felder, 1869)

$\begin{array}{llll}X & X & X & X\end{array}$

$x \quad x \quad x \quad x$

$x \quad x \quad x$

$x \quad x$

$X \quad X$

$x$

$\begin{array}{rr}x & X \\ X & X\end{array}$ 
81 Memphis neidhoeferi (Rotger, Escalante \& Coronado, 1965)

82 Zaretis callidryas (R. Felder, 1869)

83 Prepona pylene philetas Fruhstorfer, 1904

Nymphalidae: Biblidinae

84 Myscelia ethusa ethusa (Doyére, [1840])

85 Myscelia cyaniris cyaniris (Doubleday, [1848])

86 Biblis hyperia aganisa (Boisduval,1836)

87 Diaethria anna anna (Guérin-Méneville, [1844])

88 Epiphile adrasta adrasta (Hewitson, 1861)

89 Adelpha lycorias melanthe (H.W. Bates, 1864)

90 Adelpha paroeca paroeca (H. W. Bates, 1864)

91 Adelpha serpa celerio (H. W. Bates, 1864)

92 Catonephele mexicana (Jenkins \& R.G. Maza , 1985)

93 Dynamine postverta mexicana (D'Almeida , 1952)

94 Hamadryas glaucome glaucome (H. W. Bates, 1864)

95 Hamadryas fornax fornacalia (Fruhstorfer, 1907)

Nymphalidae: Nymphalinae

96 Smyrna blomfildia datis (Fruhstorfer, 1908)

97 Chlosyne lacinia lacinia (Geyer, 1837)

98 Chlosyne janais janais (Drury, 1782)

99 Anartia fatima fatima (Fabricius, 1793)

100 Vanessa atalanta rubria (Fruhstorfer,1909)

101 Vanessa virginiensis (Drury,1773)

102 Castilia eranites (Hewitson, 1857)

103 Tegosa guatemalena (H. W. Bates, 1864)

104 Eresia phillyra phillyra (Hewitson, 1852)

105 Hypanartia lethe (Fabricius, 1793)

106 Historis acheronta acheronta (Fabricius, 1775)

107 Historis odius odius (Lamas, 1995)

108 Siproeta epaphus epaphus (Latreille, [1813])

109 Siproeta stelenes biplagiata (Fruhstorfer,1907)

110 Morpho helenor montezuma (Guenée, 1859)

111 Anthanassa ardys ardys (Hewitson, 1864)

112 Anthanassa frisia tulcis (H. W. Bates, 1864)

113 Anthanassa argentea (Godman \& Salvin, 1882)

Nymphalidae: Heliconiinae

114 Heliconius charithonia vazquezae (C. \& B., 1950)

115 Heliconius hortense (Guérin-Méneville, [1844])

116 Dryas iulia moderata (Riley, 1926)

117 Dione moneta poeyii (Butler,1873)

118 Eueides isabella eva (Fabricius, 1793)

119 Agraulis vanillae incarnata (Riley, 1926)

120 Euptoieta hegesia meridiana (Stichel, 1938)

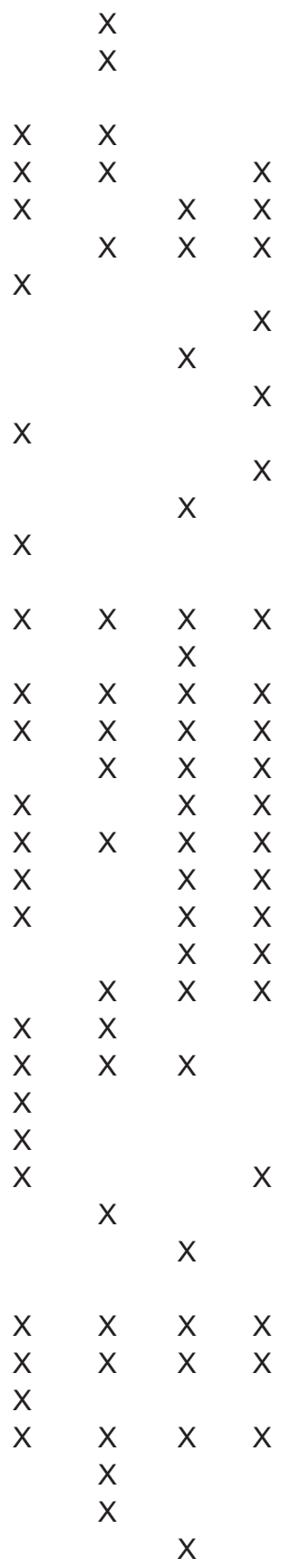




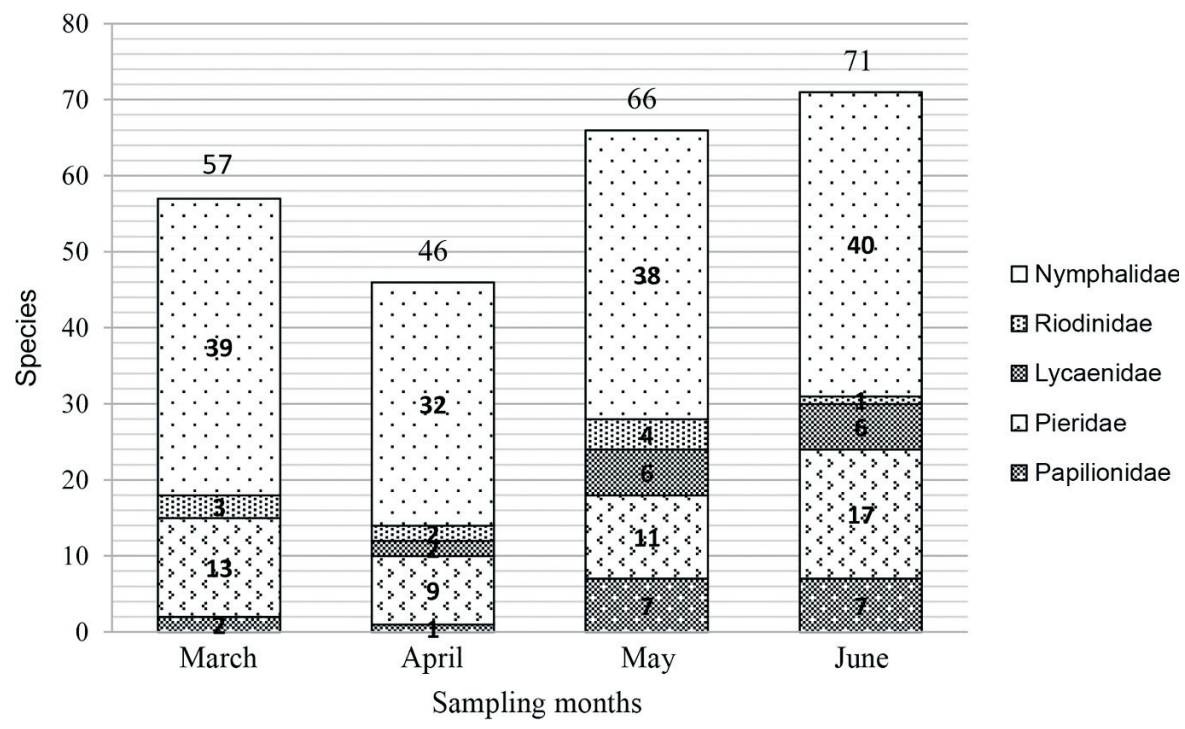

Fig. 2. Monthly species richness of families of Papilionoidea at Natura Park, Xalapa, Veracruz, México, from March to June during spring 2014.

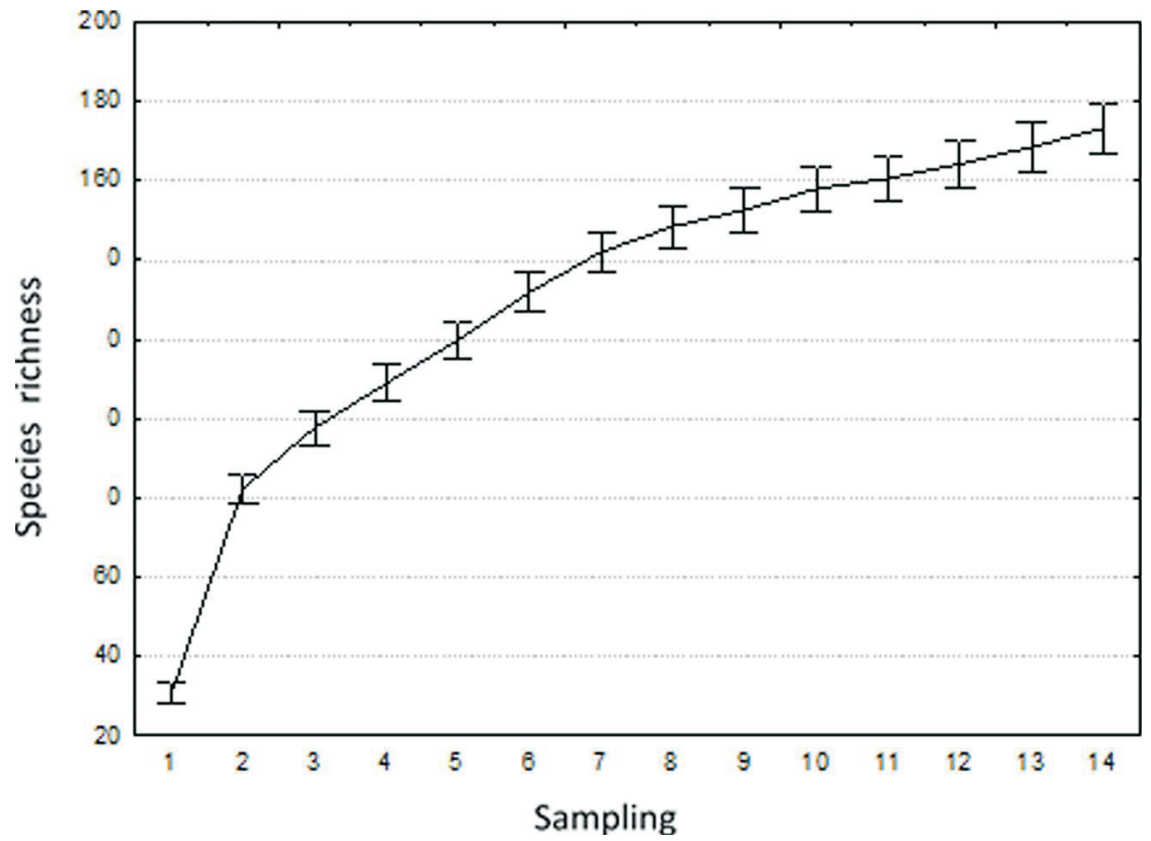

Fig. 3. Accumulation of species curve using the Chao 2 estimate for species at Natura Park, Xalapa, Veracruz, México, during spring 2014. 


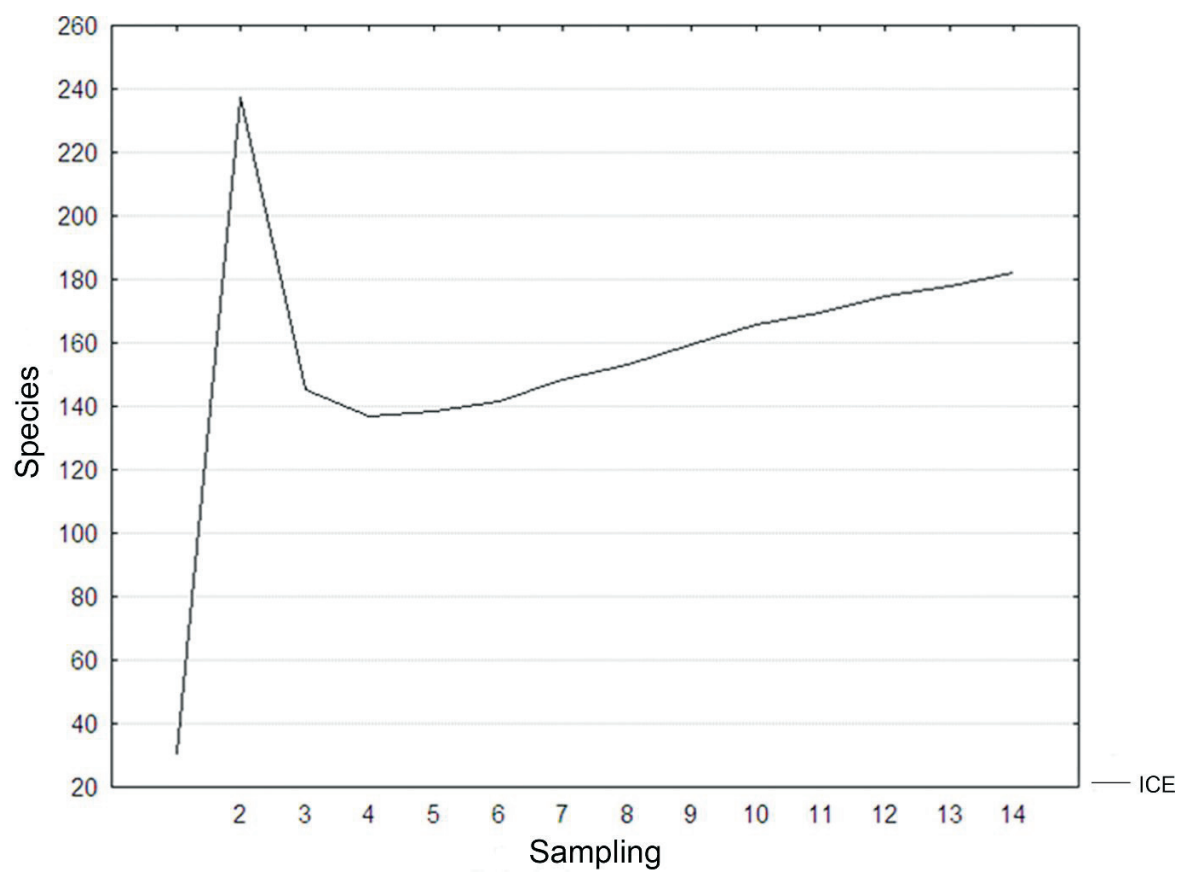

Fig. 4. Richness Independent Cost Estimates (ICE) for species at Natura Park, Xalapa, Veracruz, México, during spring 2014.

Baited traps with the largest number of specimens were those numbered 1 , 2, 4, 6, and 10 (Fig. 1). They were at sites with cloud forest and mature acahual vegetation. Because of this, we assumed the species captured were more common in better preserved areas in the park, which curiously also borders ravines of the protected region of "Tejar-Gárnica". Traps 1, 2, and 10 were about midway in the study area where vegetation was regenerating and might account for the most butterfly species collected: Trap 1 (14 species), Trap 2 (11), and Trap 10 (11). Twenty species were collected exclusively with this trapping technique. By butterfly net, 477 specimens $(61.5 \%)$ in 83 species $(70.0 \%)$ were collected.

Comparative Study. Hernández-Baz (1989) collected more than 4,000 specimens of Lepidoptera at Xalapa municipality, Veracruz, during 4 years. In total, 223 species of Papilionoidea [115 (51.5\%) Nymphalidae, 37 (16.6\%) Pieridae, 35 (15.7\%) Riodinidae, 19 (8.5\%) Papilionidae, and 17 (7.7\%) Lycaenidae] were recorded. Of the 120 species at Natura Park, the percentage of species for each family were: 68 (56.7\%) Nymphalidae, 25 (20.8\%) Pieridae, 11 (9.2\%) Lycaenidae, nine $(7.5 \%)$ Papilionidae, and seven (5.8\%) Riodinidae (Fig. 5). From the 223 species collected at Xalapa and reported by Hernández-Baz (1989, 1993), specimens were systematically obtained from January 1984 to October 1988, but also included some records from occasional collecting from 1977 to 1979 . Only 123 taxa were then reported during spring while 120 were recorded herein at Natura Park. 


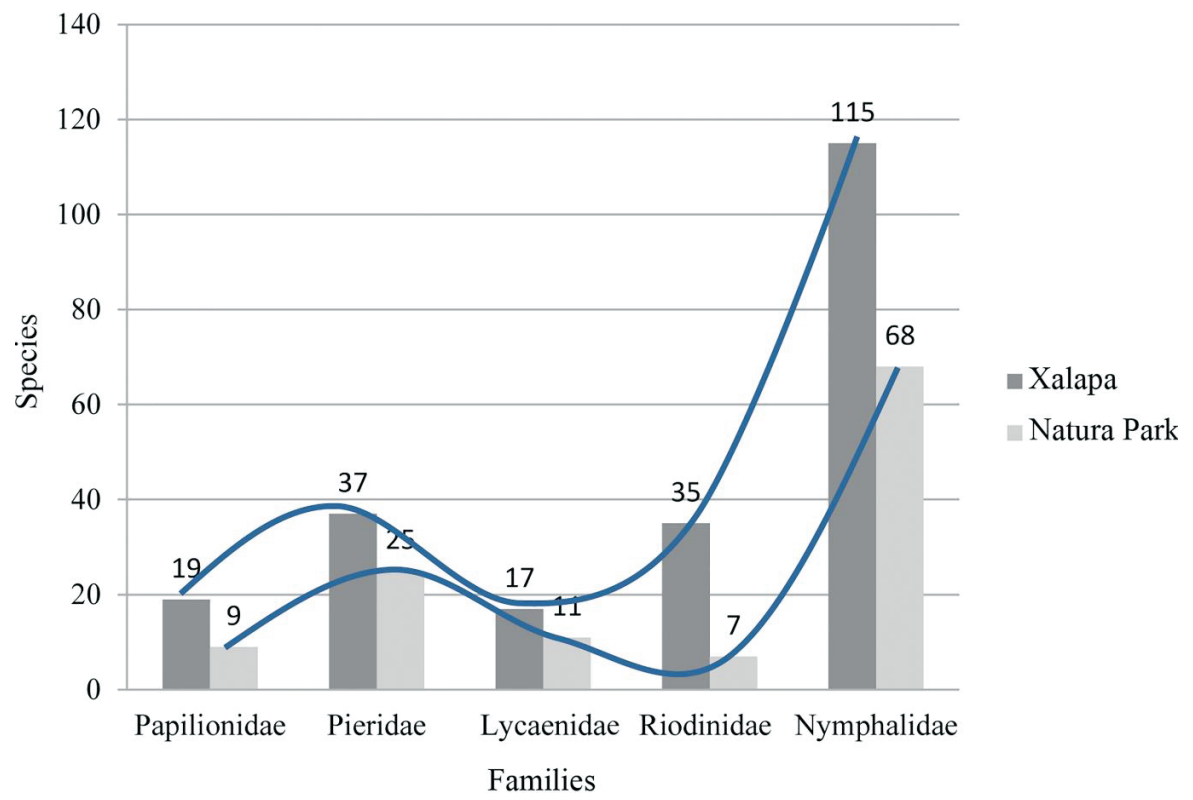

Fig. 5. Proportion of the number of species of different families of Papilionoidea reported from Xalapa by Hernández-Baz $(1989,1993)$ versus Natura Park during spring 2104.

Sixty-eight of the species collected are known only from Xalapa (HernándezBaz 1993), 64 were found exclusively at Natura Park, and 56 were common to both study sites. Hernández-Baz $(1989,1993)$ found a total of 188 species. When compared with specimens from Natura Park, we noticed similarity with Chao 2 (173 species) and Independent Cost Estimates (182 species). When the Jaccard index was applied to both locations, $70 \%$ similarity was found.

Only two species of relative importance were found. The monarch butterfly, D. plexippus plexippus, which is protected under the Nom-059-Semarnat-2010 Act, and $E$. childrenae which even though it is not protected by any state or national law, it is a threatened species (Hernández-Baz and Rodríguez 2014).

\section{Acknowledgment}

We are greatly indebted to the personnel of the Environment and Natural Resources Secretary (Secretaría de Medio Ambiente y Recursos Naturales) of Veracruz for their help. We are also thankful to Maria E. Díaz-Batres (Natural History Museum of the City of México, MHNCM) and Roberto Ortega and José Ortega (XAL Herbarium) who allowed us to study specimens in their care. This work is part of the Inventory of the Lepidopterans of the State of Veracruz, México, Project Key 223142012122, Universidad Veracruzana. JMG acknowledges financial support through the CSUF Provost's Assigned Time for Research (2016). 


\section{References Cited}

Castillo, G. 1991. Vegetación y flora del municipio de Xalapa. Instituto de Ecología, A.C.H. Ayuntamiento de Xalapa, Veracruz.

Colwell, R. K. 1997. STIMATES: statistical estimation of species richness and shared species from samples. Version 7. Department of Ecology and Evolutionary Biology, University of Connecticut.

CONABIO. 2010. El Bosque Mesófilo de Montaña en México: amenazas y oportunidades para su conservación y manejo sostenible. Comisión Nacional para el Conocimiento y Uso de la Biodiversidad. México DF, México.

Currie, D. J. 1991. Energy and large-scale patterns of animal and plant species richness. Am. Naturalist 137: 27-49.

García, E. 1988. Modificación al sistema de clasificación climática de Köppen [para adaptarlo a las condiciones de la República Mexicana], México. Publicado por el autor.

GEV (Gobierno del Estado de Veracruz). 2001. Programa de manejo El TejarGarnica, área natural protegida. Editora Gobierno del estado de Veracruz, México.

Godman, F., and I. Salvin. 1878-1901. Biologia Centrali Americana Insecta, Lepidoptera Rhopalocera. London, Dulau y Co., Bernard Quaritch 2: 782.

Hernández-Baz, F. 1989. Mariposas diurnas del municipio de Xalapa, Veracruz (Insecta: Lepidoptera) México, Taxonomía, Ecología y Zoogeografía. Tesis de Biólogo, Facultad de Biología-Xalapa, Universidad Veracruzana.

Hernández-Baz, F. 1991. Lista de tesis sobre lepidópteros (Rhopalocera. Heterocera) de México, Boletín de la Sociedad Mexicana de Lepidopterología (Nueva Serie) 1: 3-8.

Hernández-Baz, F. 1993. La fauna de mariposas (Lepidoptera: Rhopalocera) de Xalapa, Veracruz, México. La Ciencia y El Hombre 14: 55-87.

Hernández-Baz, F. 1994. La fauna de mariposas diurnas del estado de Veracruz: su diversidad y una propuesta conservacionista, pp. 75-85. In A. GonzálezChristen and A. González-Romero [eds.], Los Recursos Faunísticos del Estado de Veracruz.

Hernández-Baz, F. 2012. Biogeografía y conservación de las polillas avispa de México (Lepidoptera: Erebidae: Arctniidae Ctenuchina y Euchromiina). Editorial Académica Española, Saarbrücken, Deutschland/Alemania.

Hernández-Baz, F., and L. Iglesias A. 2001. La diversidad de orden Lepidoptera en el estado de Veracruz, México: una síntesis preliminar. Cuadernos de Biodiversidad 7: 7-10.

Hernández-Baz, F., and D. U. Rodríguez V. 2014. El Libro Rojo de la Fauna del Estado de Veracruz. Gobierno del Estado de Veracruz. Procuraduría Estatal de Protección al Medio Ambiente, Universidad Veracruzana.

Hernández-Baz, F., J. Llorente B., A. Luis M., and I. Vargas F. 2010. Las mariposas de Veracruz. Secretaria de Educación de Veracruz, Consejo Veracruzano de Ciencia y Tecnología, Gobierno del Estado de Veracruz, Universidad Veracruzana.

Hoffmann, C. C. 1940. Catálogo Sistemático y Zoogeográfico de los Lepidópteros Mexicanos. Primera parte. Papilionoidea, Anales del Instituto de Biología, UNAM 11: 639-739. 
Jiménez, V., and J. Hortal. 2003. Las curvas de acumulación de especies y la necesidad de evaluar la calidad de los inventarios biológicos. Revista Ibérica de Aracnología 8: 151-161.

Llorente, J. 1984. Sinopsis sistemática y biogeográfica de los Dismorphiinae de México con especial referencia del género Enantia Huebner (Lepidoptera: Pieridae), Folia Entomológica Mexicana 58: 1-207.

Llorente, J., A. Garcés, and A. M. Luis. 1986. Las mariposas de Jalapa-Teocelo, Veracruz (EI Paisaje Teocelo IV), Revista Teocelo 4: 14-37.

Luis, A., I. Vargas, and J. Llorente. 1995. Síntesis de los Papilionoidea (Lepidoptera: Rhopalocera) del estado de Veracruz. Folia Entomología Mexicana 93: 91-133.

Luis, A., J. Llorente, I. Vargas, and A. D. Warren. 2003. Biodiversity and biogeography of Mexican butterflies (Lepidoptera: Papilionoidea and Hesperioidea). Proceedings, Entomological Society of Washington 105: 209224.

Luis-Martínez, A., J. E. Llorente-Bousquets, I. Vargas-Fernández, and P. János. 2003. Nymphalidae de México I (Danainae, Apaturinae, Biblidinae y Heliconinae): Distribución geográfica e ilustración. Facultad de Ciencias, UNAM, CONABIO.

Luis-Martínez, A., J. E. Llorente-Bousquets, I. Vargas-Fernández, C. Pozo, and M. Rosado. 2010. Nymphalidae de México III (Nymphalinae): Distribución geográfica e ilustración. Facultad de Ciencias, UNAM, ECOSUR.

Luis-Martínez, M. A., J. E. Llorente-Bousquets, I. Vargas-Fernández, and F. Hernández-Baz. 2011. Mariposas diurnas Papilionoidea y Hesperioidea (Insecta: Lepidoptera), pp. 339-354 + apéndices. In A. Cruz Aragón [coord.], La Biodiversidad de Veracruz, Vol. 2, Comisión Nacional para el Conocimiento y Uso de la Biodiversidad, Gobierno del estado de Veracruz, México.

Moyers, L., y Z. Cano. 2009. Fenología de la comunidad de mariposas diurnas y su relación con la fenología floral de las plantas y otros factores ambientales, pp. 411-419 In A. Lot y Z. Cano-Santana [eds.], Biodiversidad del Pedregal de San Ángel. UNAM, Reserva Ecológica del Pedregal de San Ángel y Coordinación de la Investigación Científica, D.F. México.

Myers, N., R. A. Mittermeier, C. G. Mittermeier, G. A. B. da Fonseca, and J. Kent. 2000. Biodiversity hostpots for conservations priorities. Nature 403: 853-858.

Pozo, C., J. Llorente, A. Martínez, I. Vargas, I., and N. Salas. 2005. Reflexiones acerca de los métodos de muestreo para mariposas en las comparaciones biogeográficas, pp. 203-215. In J. Llorente and J. Morrone J. [eds.], Regionalización Geográfica en Iberoamérica y Tópicos Afines: Primeras Jornadas Biogeográficas de la Red Iberoamericana de Biogeografía y Entomología Sistemática (RIBES XII. I-CYTED). Universidad Nacional Autónoma de México.

Rodríguez, C. R. L. 1986. Contribución al conocimiento de la entomofauna en el campo experimental Garnica, Xalapa, Veracruz. Tesis de Biólogo, Facultad de Ciencias Biológicas, Universidad Veracruzana.

Rodríguez, L. E., A Gómez-Pompa, J. C. López A., N. Velázquez R., T. Aguilar D., and M. Vázquez T. 2011. Atlas de los espacios naturales protegidos de Veracruz. Gobierno del estado de Veracruz, Secretaria de Educación de Veracruz, Universidad Veracruzana. 
Rossignol, J. 1987. Morfoedafología del área de Xalapa-Coatepec. Descripción de las unidades del mapa morfoedafológico. Escala 1:75000.INIREB-Orstom, Xalapa, Veracruz.

Rydon, A. 1964. Notes on the use of butterfly traps in East Africa. J. Lepidopterists' Soc. 18: 51-58.

Rzedowski, J. 1978. La Vegetación de México. Edit. Limusa, México.

Soto, M., and M. Gómez. 1990. Atlas Climático del municipio de Xalapa. Instituto de Ecología, A. C. Xalapa, Veracruz.

Steyskal, G., W. Murphy, and E. M. Hoover. 1986. Insects and Mites: Techniques for Collection and Preservation. U. S. Dep. Agric. Misc. Pub. 1443: 143.

Triplehorn, C. A., and N. F. Johnson. 2005. Borror and DeLong's Introduction to the Study of Insects. 7th ed. Brooks/Cole, Thomson Learning, Inc.

Vargas-Fernández, I., J. E. Llorente-Bousquets, A. Luis-Martínez, C. Pozo, P. János, and M. Pineda. 2008. Nymphalidae de México II (Libytheinae, Ithomiinae, Morphinae y Charaxinae): distribución geográfica e ilustración. Facultad de Ciencias, UNAM y CONABIO.

Villarreal, H., M. Álvarez, S. Córdoba, F. Escobar, G. Fagua, F. Gast, H. Mendoza, M. Ospina, and A. M. Umaña. 2004. Manual de métodos para el desarrollo de inventarios de biodiversidad. Programa de inventarios de biodiversidad. Instituto de Investigación de Recursos Biológicos Alexander von Humboldt. Bogotá, Colombia.

Wilson, E. O. 1988. The current state of biological diversity, pp. 3-18. In E. O. Wilson [ed.], Biodiversity. National Academy Press, Washington, DC. 